sociedade civil constitua um terreno de articulação democrática com o Estado, promovendo o reconhecimento da diversidade e a reconstrução de identidades coletivas, o sentimento de solidariedade, o alargamento do campo de direitos e a inclusão social.

Saímos da leitura dessa coletânea mais bem instrumentalizados e mais convencidos da possibilidade de formulação de um ideário pedagógico autônomo que, diante das transformações históricas em curso nos países do continente, não continue abordando a mudança educacional como exercício de engenharia social subordinado às exigências da esfera econômica, mas encare as reformas educativas como criações culturais permeáveis ao debate intelectual e à participação societária.

Maria Clara Di Pierro

Ação Educativa - assessoria, pesquisa e informação

\section{MONTEIRO LOBATO: UM BRASILEIRO SOB MEDIDA}

\author{
Marisa Lajolo \\ São Paulo: Moderna, 2000, 99 p.
}

Ao longo dos anos, a história da literatura fixou uma imagem multiforme e um tanto contraditória de Monteiro Lobato. De uma lado, afirmase o escritor inventivo, considerado o criador de nossa literatura infantil; de outro, configura-se o crítico de pintura que tripudiou sobre os quadros inovadores da pintora modernista Anita Mafalti; ora cita-se o fazendeiro que ridicularizou seus agregados na figura do Jeca Tatu, ora exalta-se o cidadão progressista defensor do petróleo nacional. O novo livro de Marisa Lajolo, Monteiro Lobato: um brasileiro sob medida, vai além dessa imagem, mostrando que a carreira poliédrica do escritor foi fruto de uma visão de mundo arrojada e moderna, sempre em perfeita sintonia com o seu momento histórico.

O livro de Marisa começa como uma biografia sentimental e até convencional. Nos capítu- los iniciais, a autora confessa as raízes infantis do seu encanto pelo escritor, acompanha os primeiros passos de Lobato nos meios escolares, narra a quase obrigatória passagem pelas arcadas da faculdade de Direito de São Paulo e a atividade de fazendeiro-escritor nas terras herdadas do avô visconde. Mas, aos poucos, vai se desvelando para o leitor a personalidade rica e vigorosa de Lobato, que passa de escritor para "escritor-editor de si mesmo, e finalmente editor de obras alheias", percorrendo uma trajetória pontuada de "impasses, hesitações e remorsos".

Apesar dos momentos de dúvida, o perfil do escritor-editor se afirma com todo seu vigor. Em uma época em que a qualidade gráfica dos livros era considerada fator irrelevante para os editores brasileiros, Lobato intui que a aparência do produto era indispensável para atrair a atenção dos leitores. Contrata artistas plásticos para modernizar as capas e ilustrar os textos, assim imprimindo uma feição artística na materialidade do livro. Faz considerações sobre a importância da censura e do escândalo como desencadeadores de venda de um livro, ou ainda, discute a diversidade de interesses entre escritor e editor. Essa concepção utilitária da literatura é ousada para os anos 20, mas, como diz Marisa Lajolo, está em sintonia com seu tempo, pois então "o Brasil timidamente se moderniza, e se moderniza numa direção capitalista".

Outro tema abordado na biografia, como não poderia deixar de acontecer, são os livros infantis, considerados pela autora como a mais bela invenção de Lobato. Aqui, entretanto, a obra lobatiana é vista sob um ângulo novo, pois Marisa vai além das apreciações textuais e mostra que a saga do Sítio do Picapau Amarelo foi um verdadeiro "projeto literário e pedagógico sob medida para - Brasil”. Logo após publicar seu primeiro livro, Narizinho arrebitado, o autor transfere a experiência de editor de literatura adulta para a realidade mercadológica do livro infantil. Conhecedor do papel fundamental da escola e do Estado na difusão da leitura, dá o primeiro impulso a sua obra infantil distribuindo gratuitamente 500 exemplares de Narizinho arrebitado às escolas públicas 
paulistas. $\bigcirc$ sucesso entre os leitores mirins, que deixava o livrinho surrado, impressionou o governador Washington Luís em suas visitas às escolas, fato que levou o secretário da Educação Alarico Silveira a fazer uma compra de 30 mil exemplares!

Sempre atento a sua realidade, Lobato soube incorporar, em uma obra ficcional pautada pela fantasia e pelo humor, informações muitas vezes coincidentes com o currículo escolar. Em contraposição à escola convencional, alvo de freqüentes críticas das personagens lobatianas, o Sítio do PicaPau Amarelo surge como uma escola alternativa. Nela, conhecimentos de gramática, matemática, geologia e até rudimentos de uma política nacionalista de petróleo são veiculados e assimilados de forma crítica, independente e freqüentemente questionadora, especialmente quando a relação de ensino-aprendizagem se dá entre Dona Benta e a discípula Emília.

Nos anos 40, quando ainda nem se pensava em Mercosul, o autor acalentou um desdobramento latino-americano de sua obra, por meio de um projeto em que a história da América fosse contada às crianças pelo vulcão andino Aconcágua. O projeto, que não chegou a ser implementado, é inovador e ousado, tanto no plano intelectual como editorial. Primeiro, porque propõe um novo modo de contar a história da América, isto é, a partir de um ponto de vista diferente do colonizador europeu. Segundo, porque procura ampliar o mercado de leitores, atingindo um público além de nossas fronteiras.

Outro fator que atesta a modernidade de Lobato foi sua capacidade de conquistar os leitores mirins. Este é o caso do coloquialismo da voz narrativa, recurso inédito nas histórias infantis brasileiras, até então conduzidas por um narrador de voz impostada. Segundo o escritor paulista Afonso Schmidt, as primeiras obras para crianças brasileiras eram histórias francesas recontadas por tradutores portugueses, cujo vocabulário era incompreensível até para os adultos. Embora as publicações infantis tenham evoluído com os escritores nacionais, como Olavo Bilac, João do Rio e Viriato Correia, Schmidt afirma que a grande virada só aconteceria com Lobato, o primeiro a escrever "na língua da gente". Outro recurso ficcional inaugurado na saga do Sítio do Picapau Amarelo, hoje empregado pelos autores infantis, é o formato seriado da obra, que repete o mesmo espaço e os mesmos personagens, elemento fundamental para manter a fidelidade dos leitores.

Do escritor de obras adultas, a biógrafa destaca as personagens de Jeca Tatu, Jeca Tatuzinho e sua última versão, Zé Brasil. Entre eles, decorrem 30 anos de evolução política de Lobato. Com o Jeca Tatu, temos a crítica impiedosa do jovem fazendeiro contra a indolência do caipira; já o Jeca Tatuzinho é visto pela ótica compreensiva do escritor maduro que revê a personagem como vítima da subnutrição e das endemias que assolavam a saúde do brasileiro. E um ano antes da morte do autor, chegamos à declaração de luta entre o latifundiário Tatuíra e o Zé Brasil. Trata-se, agora, de uma criação integrada em um novo contexto econômico e político, o "da propriedade da terra, da questão rural, da política agrária, das organizações de esquerda".

Outro livro comentado pela autora é $O$ choque das raças ou $O$ presidente negro, ficção científica que trata dos problemas raciais na sociedade norte-americana do ano 2228. Lobato leva os originais para os Estados Unidos, para onde se muda em 1927, investido no cargo de adido comercial brasileiro. Entusiasmado com o dinamismo do país, tenta publicar a obra com a finalidade de penetrar no mercado norte-americano. Um editor local acena com a possibilidade de publicá-lo desde que o escritor adequasse o livro à realidade mercadológica do país. A proposta, que inclui desde o acirramento do tema racial até a provocação de um escândalo literário, é admitida e até ampliada pelo escritor. Segundo Marisa Lajolo, embora o livro não tenha sido publicado, o episódio é significativo pois mostra que no projeto de Lobato para o Presidente negro não há "mais lugar para a imagem ingênua do escritor para quem a produção de um texto corresponde a uma necessidade de expressão íntima, como reza a tradição romântica". 
Monteiro Lobato: um brasileiro sob medida trata ainda de outros momentos da vida do grande escritor, como a publicação de $O$ escândalo do petróleo, a elaboração de seu projeto petrolífero para o país, os problemas com o governo, o exílio na Argentina, a simpatia por Luís Carlos Prestes, o final de vida de amargura, apesar do reconhecimento do público. Vale a pena ressaltar que os fatos e as interpretações da biografia, fruto de anos de pesquisa da autora, são relatados em uma linguagem clara e agradável, em um tom elegantemente coloquial. No final do volume, foram incluídos uma bibliografia comentada sobre o autor e um quadro cronológico contendo os principais acontecimentos da biografia e do momento histórico em que viveu o escritor.

O projeto gráfico do livro, assinado por Moema Cavalcanti, é uma verdadeira homenagem ao editor Lobato, a começar pelo formato pouco usual (mais largo que alto) do volume, que lembra os livros infantis. Também digno de nota é o uso da cor forte e vivaz que acompanha a capa com a foto do escritor, as folhas de guarda, as antigas ilustrações das personagens infantis (que infelizmente não trazem o crédito dos artistas que as desenharam), enfim, todos os detalhes decorativos que permeiam a obra. Finalmente, as ilustrações com fotos de São Paulo antigo e reproduções de algumas das lindas capas encomendadas pelo editor Lobato. Por tudo isso, o livro deve agradar tanto aos especialistas em literatura e cultura brasileira como aos leitores leigos que gostam de uma boa e bonita biografia.

Maria Célia Paulillo

Centro Universitário Fundação Instituto de Ensino para Osasco - Unifieo/SP 